\title{
Influence of stormwater infiltration on the treatment capacity of a LECA-based horizontal subsurface flow constructed wetland
}

\author{
L. Amado ${ }^{a}, A$. Albuquerque $^{b, *}, A$. Espírito Santo ${ }^{c}$ \\ a Department of Civil Engineering, Polytechnic Institute of Guarda, Av. Dr. Francisco Sá Carneiro, no. 50, 6300-559 Guarda, Portugal \\ ${ }^{\mathrm{b}}$ Department of Civil Engineering and Architecture, University of Beira Interior, Bloco II das Engenharias, Calçada do Lameiro, 6201-001 Covilhã, Portugal \\ ${ }^{\mathrm{c}}$ Department of Electromechanical Engineering, University of Beira Interior, Bloco II das Engenharias, Calçada do Lameiro, 6201-001 Covilhã, Portugal
}

\section{A R T I C L E I N F O}

\section{Article history:}

Received 26 June 2011

Received in revised form

21 September 2011

Accepted 21 November 2011

Available online 17 December 2011

\section{Keywords:}

Constructed wetlands

Subsurface flow

Infiltration

Hydraulic loading rate

Pollutant removal

\begin{abstract}
A B S T R A C T
This research work evaluates the impact of stormwater infiltration on the removal of organics, solids, nitrogen and phosphorus in a LECA-based horizontal subsurface flow constructed wetland. Stormwater runoff for the period between January 2008 and June 2010 (30 months) was estimated for the drainage basin of the Vila Fernando wastewater treatment plant (constructed wetland system) and it was observed proportionality between the increase in surface runoff and the infiltration flow rate that reached the plant. The average stormwater infiltration rate that reached the plant was $67.4 \mathrm{~m}^{3} \mathrm{~d}^{-1}$ (77\% of the influent flow rate into the plant). The 30 month monitoring campaign set up at one of the reed beds showed that stormwater infiltration led to a high variation of the hydraulic loading rate (HLR) throughout the bed, which affected its performance in the removal of organic matter, suspended solids and nitrogen. For a HLR below $20 \mathrm{~cm} \mathrm{~d}^{-1}$ the removal efficiencies for $\mathrm{BOD}_{5}$, COD and TSS doubled. The removal of nitrogen was too low and was associated with the weak development of nitrifying biofilm and the poor growth of reeds. However, it was observed a good relationship between the applied and removed loads for most of the parameters, which seems to indicate that the organic, solid, nitrogen and phosphorus loading rates influenced the respective removal rates. The use of a bed material with high specific surface area, such as LECA, can only improve the treatment capacity of horizontal subsurface flow systems if the organic and solid loading rates, as well as the HLR, can be effectively controlled.
\end{abstract}

(C) 2011 Elsevier B.V. All rights reserved.

\section{Introduction}

Constructed wetlands (CW) appear as an economically, technically and environmentally sustainable alternative solution for small population communities, especially in rural areas and around big cities. Besides providing both secondary and tertiary/polishing treatment, which is especially useful when the receiving waters are considered sensitive or the water reuse is an option (Randerson, 2006; Kadlec and Wallace, 2008; Marecos do Monte and Albuquerque, 2010), it is also a system well accepted by the population and well integrated in the landscape.

The entry of stormwater into the sewer network (infiltration) is common and difficult to estimate. Its variation and dimension depend on factors such as the conservation status of the sewer network, physical changes in the drainage catchment (e.g. change in land cover or impermeable area), the groundwater level and

\footnotetext{
* Corresponding author. Tel.: +351 275 329981; fax: +351 275329969.

E-mail addresses: ligia@ipg.pt (L. Amado), ajca@ubi.pt (A. Albuquerque), aes@ubi.pt (A. Espírito Santo).
}

the volume of stormwater runoff, which may adversely affect the downstream wastewater treatment and increase the operation and maintenance costs of wastewater systems (Wade, 2000; Cardoso et al., 2005).

The hydraulic loading rate (HLR) is a critical parameter for the operation of horizontal subsurface flow constructed wetlands (HSSF-CW). The infiltration of stormwater flow into the sewer network may increase the HLR throughout the beds. If loading is too high $\left(>30 \mathrm{~cm} \mathrm{~d}^{-1}\right)$, the bed tends to clog causing wastewater to back up or hydraulic short-circuiting, which may lead to the discharge of low quality effluents into water streams (Wallace and Knight, 2006; Vymazal and Kropfelova, 2008). Inert and slowly degradable solids, excessively thick and sloughing biofilms, and anaerobic environments (as occurs in HSSF beds) may cause the development of mineral deposits and microbial slimes, which also contribute to bed clogging. The bed clogging leads to resistance to flow and, therefore, to a decrease in treatment performance. The excess of particulate organics and solids may also worsen the treatment capacity of HSSF-CW as observed in Albuquerque et al. (2009a).

The use of light-expanded clay aggregates (LECA) is pointed out as an alternative solution to minimize the clogging problem 